\title{
Defining Suburbs
}

\section{Citation}

Forsyth, Ann. 2012. Defining Suburbs. Journal of Planning Literature 27, no. 3: 270-281.

\section{Published Version}

doi:10.1177/0885412212448101

\section{Permanent link}

http://nrs.harvard.edu/urn-3:HUL.InstRepos:16139611

\section{Terms of Use}

This article was downloaded from Harvard University's DASH repository, and is made available under the terms and conditions applicable to Open Access Policy Articles, as set forth at http:// nrs.harvard.edu/urn-3:HUL.InstRepos:dash.current.terms-of-use\#OAP

\section{Share Your Story}

The Harvard community has made this article openly available.

Please share how this access benefits you. Submit a story.

\section{Accessibility}




\title{
Defining Suburbs
}

Forsyth A. 2013. Journal of Planning Literature 27, 3: 270-281.

\begin{abstract}
There is no consensus as to what exactly constitutes a suburb. This paper examines the range of suburban definitions in terms of their structure and the topical issues that they grapple with. Suburbs have been defined according to many different dimensions from location and transportation modes to culture and physical appearance. Given this confusion, one approach is to abandon the term; another is to use it with greater precision. This is more than just an issue of semantics. Rather how people talk and think about suburbs shapes how they can see such areas being developed and redeveloped in the future.
\end{abstract}




\section{Defining Suburbs}

\section{The Problem of Definition}

What is a suburb? In the coming decades billions of people will move to urban areas. The middle projection from the United Nations is that from 2010 to 2050 the world's urban population will increase from 3.5 billion to 6.3 billion, that is by $80 \%$ (U.N. 2010, 29; Clapson and Hutchinson 2010). Many of these new urban dwellers will live in areas that are suburban. How many people, and what that means, depends heavily on how suburbs are defined. This paper explores this issue of how to define suburbs. This is more than just an issue of semantics. As a vibrant literature on framing in planning work suggests, how urbanists, the press, and the public talk and think about suburbs shapes how they can see such areas being developed and redeveloped in the future (Caplan and Nelson, 1973; Rein and Schon 1994; Healey 2009). In coming decades, as new suburban areas are built and older ones head toward redevelopment, clearer definitions, or better alternatives to the term suburb, can help focus academic and practical debates on important issues.

In 1958 Kurtz and Eichler published an article in Social Forces complaining about confusion over "residence categories" and in particular the terms "suburb" and "fringe." As they pointed out, when concepts are not clear it is hard to create adequate theory. Of course this problem of poor definitions is not only confined to the term "suburb," In 1955 Hillery published a famous article on definitions of "community" in sociology. "Community" is surely a key topic in that discipline but Hillery examined 94 different definitions and the only thing they had in common was they all contained people.

The situation has not improved much in the more than half century since Kurtz and Eichler published their complaint. As Lineberry $(1975,2)$ argued in the mid-1970s "despite the voluminous literature on suburbia, we are no closer than ever to a definition. It is a mere assumption of convenience that we all know what we are talking about, however variegated the pictures in our heads." While Lineberry attempted to provide some clarity, suburbia has proven to be a tough concept to define. In 2010 Harris, reviewing the international literature on suburbs, still complained that the field needed to establish a "minimum definition to which suburbs everywhere conform" (Harris 2010, 26; Harvard Law Review Association 2004). Even among urban scholars, then, there is no consensus as to what exactly constitutes a suburb. The plethora of meanings expands when one includes popular and media accounts.

This paper examines the range of suburban definitions in terms of their structure and the topical issues that they grapple with. These include definitions focused on physical, functional, social, and process dimensions as well as others taking a more analytical or critical view. Obviously definitions of terms such as suburbs are social constructions or deliberate abstractions, focusing attention on some aspects of suburbs and not others. Which aspects are focused on depends in part on the aims of the authors - which can be quite varied.

In preparing this review I examined definitions from several related areas in urban studiesprimarily urban planning, urban history, urban sociology, and urban geography. There are 
certainly some disciplinary differences in terms of definitions. For example historians are striving to define suburbs in a way that makes sense over time and urban sociologists are particularly concerned about social relations. Those working in low-income countries often use an overlapping term-peri-urban development-that most commonly refers to the urban or suburban fringe but may also refer to areas less far out (Adell 1999; laquinta and Drescher 1999). Overall, there are almost as many differences within these fields in terminology as between them and a great deal of overlap among the fields.

Given this multiplicity of definitions, one approach is to abandon the word, replacing it with terms referring to specific types of suburbs or particular features such as density. This has some advantages in terms of reducing ambiguity. However, it can also be argued that focusing on key dimensions misses the big picture of metropolitan growth and change. For those wishing to define suburbs as a whole, the most practical approaches have been based on suburbs' location in the metropolis and relative newness.

In identifying definitions for this paper I encountered a difficulty, however. Surprisingly few people who write about suburbs actually define them explicitly as a whole-including many classic, influential, and otherwise important works on suburbs. Some focus on specific types of suburbs defining them quite clearly but not dealing with suburbs more generally-for example authors may focus on ethnoburbs, technoburbs, suburban master planned communities, or streetcar suburbs. Some of my own work has taken this form. Others define suburbs through examples by applying the term suburban to particular places or characteristics from which a definition can be deduced by the reader. However, it is hard to piece together a comprehensive definition from such accounts. Yet others focus on areas that are clearly suburban by many definitions-for example new developments of detached housing on the urban fringe. However, they do not pay much attention to articulating whether other kinds of developments are also suburban.

In order to locate more explicit and comprehensive definitions, I started by reviewing sources likely to define suburbs, such as census agency manuals. I looked at books on suburbs, searching via the combined library catalog, Worldcat. In addition I located literature using Google Scholar, applying key words such as variants on the terms "suburb" and "definition." I also searched using questions such as "what is a suburb?" I started with Google Scholar because it picks up a wider variety of sources than, for example, Web of Knowledge (ISI/Thompson). One assessment in social work found it located four times the number of disciplinary journals (Hodge and Lacasse 2011). It also is very simple to search for works that have cited a particular piece. However, I also checked my search against several other databases including Web of Knowledge, Summon (a database aggregator used by libraries-my library had 800 million references in the database), and the Avery Index to Architectural Periodicals. Combined, these other databases added four more relevant references, all from Summon.

In this way I traced a range of authors who defined suburbs. More importantly I examined the articles and books they cited and located works that cited the sources I had found. Some of 
these also provided definitions. I did not intend to inventory every work defining suburbs but rather to show the range of definitions across the century in which the urban studies literature has grappled with the phenomenon of suburbanization. I took this historical approach because a number of definitional issues - such as whether suburbs are essentially residential or can contain employment areas - are longstanding, but that situation is not always obvious from recent debates. While drawing mainly on work from the U.S., U.K., and Australasia, where possible the paper extends more globally within the English-language literature.

\section{Why Definitions Matter}

Why does better defining suburbs matter for urban studies and planning? People have been discussing and studying suburbs for decades without any consistent definition so perhaps there is no need for one. There are a number of reasons, however, why it is important to define suburbs clearly.

First, is the issue of action. As Caplan and Nelson $(1973,200)$ pointed out some decades ago in the context of social problems, "what is done about a problem depends on how it is defined" (also Schon and Rein 1994; Healey 2009). In the field of urban planning, scholars have pointed to the importance of framing issues in debates about such topics as growth patterns and affordable housing in suburbs (e.g. Bassett 2007; Forsyth 1999; Goetz 2008). However, this is not only restricted to debates in suburban locations but is relevant to debates about suburbs themselves. For example, if suburbs in the United States are seen as essentially white and middle class or elite, policy makers may pay less attention to the real achievements and problems of African-American suburban residents or low-income suburbs. If they are seen as essentially automobile dependent the many examples of transit-oriented suburbs may be ignored. In public debates, people talk past each other if they are not talking about the same thing.

Second is the problem of research and theory. Conducting empirical research requires adequate definitions of features and concepts being measured. As Kurtz and Eichler (1958) argued in the 1950s, it is difficult to develop an adequate theory of suburbs if terms are not clearly defined. If one study defines suburbs as metropolitan municipalities outside the central city and another as places that are dominated by detached housing, they will be examining different areas making comparisons and generalizations more difficult. While researchers may themselves be careful about such issues, those using research findings may well miss these subtle differences and misinterpret the implications.

Finally, even if one does not consider that clear definitions matter for theory and practice, it is still worthwhile to review the variety of definitions to help reduce confusion in the field. Such a review provides scholars, students, and practitioners with a roadmap for identifying the perspectives of authors. 


\section{Forms of Definitions}

Analyzing how suburbs are defined is not easy because the way definitions of suburbs are constructed varies quite a bit even among those authors who define suburbs explicitly. Figure 1 explains some of these differences.

- First, is whether the definition proposes what a suburb is (also called a positive definition) or focuses on what it is not or what it lacks (also called negative). This is not the same as whether the author likes suburbs or not. A positive definition, of what a suburb is, may focus aspects of suburbia seen as problematic by the analyst (e.g. that it is automobile oriented); similarly a negative definition, of what a suburb lacks, may focus on the absence of problems.

- Second, and cutting across this first issue, is whether the definition focuses on a core essence of "suburbanity" for example that all suburbs, or the most typical suburbs, have low densities and are primarily residential, or lists a set of features or types of suburbs that hang together with a family resemblance (Wittgenstein 2009). Many definitions revolving around features and types are quite complex, which is part of the reason they were not reduced to an essence.

Figure 1: Approaches to Defining Suburbs Explicitly

\begin{tabular}{lll}
\hline & Core essence & $\begin{array}{l}\text { Features and types (family } \\
\text { resemblance) }\end{array}$ \\
\hline $\begin{array}{l}\text { What a } \\
\text { suburb is/ } \\
\text { positive }\end{array}$ & $\begin{array}{l}\text { Example: Low density primarily } \\
\text { residential areas }\end{array}$ & $\begin{array}{l}\text { Example: First, second, and third ring } \\
\text { suburbs; suburbs as low density, with } \\
\text { detached houses, middle class families, } \\
\text { substantial open space, and scattered } \\
\text { employment }\end{array}$ \\
\hline $\begin{array}{l}\text { What a } \\
\text { suburb lacks/ } \\
\text { negative }\end{array}$ & $\begin{array}{l}\text { Example: Suburbs are within } \\
\text { metropolitan areas (not rural) } \\
\text { and outside the central cities } \\
\text { (not core) }\end{array}$ & $\begin{array}{l}\text { Example: Not cultured, not diverse, } \\
\text { unequal, not dense }\end{array}$ \\
\hline
\end{tabular}

Whether a relatively simple or complex definition, examining what suburbs are or what they are not, focused on an essence or features, several key topics often appear in definitions of suburbs. Table 1 demonstrates some of these and they are dealt with in more detail later in the paper. These reflect definitions of suburbs as a whole-the list would expand if the paper was focused on defining specific types of suburbs. What is obvious from the short listing, however, is how varied the dimensions are and how potentially complicated definitions become when dimensions are combined. 
Table 1: Key Dimensions for Defining Suburbs with Examples of Definitions

\begin{tabular}{|c|c|c|}
\hline Dimension & Brief description & Examples \\
\hline \multicolumn{3}{|l|}{$\begin{array}{l}\text { Physical (where, } \\
\text { what) }\end{array}$} \\
\hline Location & $\begin{array}{l}\text { Where the suburbs are } \\
\text { located within a } \\
\text { metropolitan area }\end{array}$ & $\begin{array}{l}\text { Suburbs as on the outskirts of a the town; } \\
\text { definition unofficially derived from U.S census } \\
\text {-- suburbs as within metropolitan areas but } \\
\text { outside of core cities }\end{array}$ \\
\hline $\begin{array}{l}\text { Built environment } \\
\text { characteristics }\end{array}$ & $\begin{array}{l}\text { Key physical features related } \\
\text { to development patterns or } \\
\text { building types; local visual } \\
\text { identity }\end{array}$ & $\begin{array}{l}\text { Suburbs as having large areas of low density } \\
\text { detached houses }\end{array}$ \\
\hline \multicolumn{3}{|l|}{$\begin{array}{l}\text { Functional } \\
\text { (operations) }\end{array}$} \\
\hline Transportation & $\begin{array}{l}\text { How people access and get } \\
\text { around in suburbs }\end{array}$ & $\begin{array}{l}\text { Suburbs as locations within commuting } \\
\text { distance of a core city }\end{array}$ \\
\hline Activities & $\begin{array}{l}\text { Functions and uses of the } \\
\text { place }\end{array}$ & $\begin{array}{l}\text { Suburbs as mainly residential developments } \\
\text { with segregated uses }\end{array}$ \\
\hline \multicolumn{3}{|l|}{ Social (who) } \\
\hline Political places & $\begin{array}{l}\text { Defined by municipal or } \\
\text { similar boundaries }\end{array}$ & $\begin{array}{l}\text { U.S. definition of suburbs as municipalities } \\
\text { outside the core city, affecting policies such as } \\
\text { education and zoning }\end{array}$ \\
\hline Sociocultural & $\begin{array}{l}\text { The population character, } \\
\text { level of exclusivity, and } \\
\text { cultural heritage and tastes }\end{array}$ & $\begin{array}{l}\text { Suburbs as middle class or exclusive; a } \\
\text { suburban way of life }\end{array}$ \\
\hline \multicolumn{3}{|l|}{$\begin{array}{l}\text { Process (how, } \\
\text { when) }\end{array}$} \\
\hline $\begin{array}{l}\text { Styles of building, } \\
\text { design, and } \\
\text { planning }\end{array}$ & $\begin{array}{l}\text { Who builds; the level of } \\
\text { planning in terms of } \\
\text { amounts of control and } \\
\text { scale of planning unit }\end{array}$ & $\begin{array}{l}\text { Suburbs as incremental and speculative } \\
\text { developments }\end{array}$ \\
\hline Time & $\begin{array}{l}\text { Relates to relative newness, } \\
\text { or its period of development }\end{array}$ & $\begin{array}{l}\text { Suburbs as areas from the period since the } \\
\text { second world war }\end{array}$ \\
\hline \multicolumn{3}{|l|}{ Analytical } \\
\hline $\begin{array}{l}\text { Critical } \\
\text { assessments }\end{array}$ & Suburbs seen as problematic & $\begin{array}{l}\text { Suburbs as sprawling, conformist, isolating, } \\
\text { elite, locationally disadvantaged, and/or ugly } \\
\text { places; often opposed to the core city }\end{array}$ \\
\hline Indices & $\begin{array}{l}\text { Defined using criteria } \\
\text { combined into some kind of } \\
\text { indicator }\end{array}$ & Sprawl indices, fiscal capacity classifications \\
\hline
\end{tabular}

Sources: See rest of paper.

First are definitions focused on physical dimensions such as where the suburb is located in the metropolitan area and its general built environment characteristics such as low densities. Next are definitions related to how suburbs function, for example transportation modes or typical 
activities in suburbs (residential, mixed use). Other definitions deal with broadly social dimensions related to how people interact either politically (whether suburbs have their own governments) or culturally (often related to issues of diversity, exclusivity, and whether there is a distinctive suburban way of life). The issue of process and time is the focus of a fourth set of definitions that typically come up with a comprehensive set of suburbs from a list of types. Some of these focus on who builds the suburb (e.g. developer, self-build) or design and planning styles and others on the period or newness of suburbs. Finally, a number of more analytical definitions either define suburbs in terms of problems-for example that they are sprawling or conformist--or try to come up with more neutral, data-based classifications such as sprawl indices.

Many definitions of suburbs as a whole incorporate several dimensions at once meaning they are quite complex. Some examples below give a flavor of these combinations; the dimensions they represent are indicated in figure 2 . The implication is that while much of this paper focuses on single dimensions, many definitions combine at least two of them. For example:

- Gober and Behr (1982) used discriminant analysis to check the importance of nine characteristics thought to distinguish suburbs from core cities in the United States including age/family status, ethnicity, income, density, auto-orientation, housing age, and employment in manufacturing, retail, and services. They found race and ethnicity to be the most important variable distinguishing central cities and suburbs in the U.S. at the time (Gober and Behr 1982, 375).

- Harris and Larkham $(1999 b, 8)$ used historical and geographical approaches to note five characteristics of suburbia focusing on North America and the U.K.: (1) peripheral location; (2) residential character; (3) low density with perhaps high levels of owner occupancy; (4) a distinctive way of life; (5) separate identities for communities often at the municipal level.

- Writing a decade later, and attempting to provide a truly global definition, Harris recast suburbs as having three dimensions internationally-(1) "peripheral location", (2) (usually) having "residential densities intermediate between those of the city and the country", and (3) relative "newness" (Harris 2010, 27, 29).

- Johnson (2006, 261), a geographer working in Australia, saw Harris and Larkham's (1999) definition as being relevant but added her own: "the idea of a single storied, freestanding dwelling on a relatively large allotment, in a mainly residential area, with strong local identity and limited governance, located midway between the city centre and rural lands, where women tend to children and community while their husbands journeyed elsewhere for paid work, encapsulates the Australian suburb." The expansion of Australian cities, she pointed out, had provided an array of different types including "the nineteenth-century 'inner suburbs' within walking distance of the city centre, thence the early twentieth-century 'middle suburbs' connected to the city by public tramways and railways and, with the mass ownership of private cars from the 1950s, to the 'outer suburbs' beyond" (Johnson 2006, 261).

Johnson went on to argue that suburbs were changing-in terms of household types, "house forms, density, retailing, employment, outlook and voting behavior" so that 
suburbs had fundamentally departed from this definition, at least in a number of major Australian cities (Johnson 2006, 261).

- Journalist Flint $(2006,2)$, focusing on the situation in the U.S. simply described "suburbia-spread-out, drive-thru, car-dependent, newer-the-better suburbia." This simple definition combines the dimension of density, newness, and dominant transportation mode.

Figure 2: Example Definitions Categorized by Dimensions Dealt With

\begin{tabular}{|c|c|c|c|c|c|c|c|c|c|c|c|}
\hline & & & 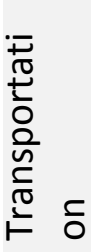 & & & $\frac{1}{\mathrm{o}}$ & 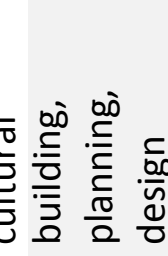 & & $\stackrel{\overline{\mathbb{U}}}{.0}$ & 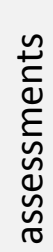 & \\
\hline Gober and Behr 1982 & & $\mathbf{x}$ & $\mathbf{x}$ & $\mathbf{x}$ & & $\mathbf{x}$ & $\mathbf{x}$ & & & & $\mathbf{x}$ \\
\hline Harris and Larkham 1999b & $\mathbf{x}$ & $x$ & & $\mathbf{x}$ & & $\mathbf{x}$ & & & & & \\
\hline Harris 2010 & $\mathbf{x}$ & $x$ & & & & & & $\mathbf{x}$ & & & \\
\hline Johnson 2006 & $\mathbf{x}$ & $x$ & $x$ & $x$ & $x$ & $\mathbf{x}$ & $x$ & $x$ & & $x$ & \\
\hline Flint 2006 & & $\mathbf{x}$ & $\mathbf{x}$ & & & & $\mathbf{x}$ & & & & \\
\hline
\end{tabular}

Obviously different authors have different emphases related to their substantive interests and the countries authors are studying. They also reflect the changing character of suburbs over time-both in one location such as the Australian suburbs described by Johnson, and between places.

Of course not all definitions are essentialist, some that can be better seen as locating a family resemblance list features and types of suburbs. Figure 3 provides a small sampling of these features for just two dimensions. For example suburbs may vary from socially homogenous to socially-mixed in terms of their sociocultural character, and in terms of style may be built at a large scale by a developer or house by house by an owner. Combining just these two dimensions creates an amazing variety of suburban types, most of which actually exist, e.g. both large-scale homogenous and socially mixed suburbs, and built-by-owner homogenous or mixed suburbs. One form of definition would list these types. In this case, however, it is obvious that one would also have to add another dimension to distinguish developments in the core city or small towns from these suburbs-common criteria would be outer location or relative newness. 
Figure 3: Example Continua

\begin{tabular}{|c|c|c|c|}
\hline Dimension & Extreme 1 & & Extreme 2 \\
\hline Sociocultural & Socially homogenous & & Socially mixed \\
\hline Sociocultural & $\begin{array}{l}\text { Residence by choice for } \\
\text { all groups }\end{array}$ & & $\begin{array}{r}\text { Economic and/or } \\
\text { regulatory exclusion; } \\
\text { resettlement }\end{array}$ \\
\hline Sociocultural & Low cost & & $\begin{array}{r}\text { High income elite } \\
\text { developments }\end{array}$ \\
\hline Style & $\begin{array}{l}\text { Large scale } \\
\text { developer/builders }\end{array}$ & $\begin{array}{l}\text { Middle sized builders } \\
\text { doing small subdivisions }\end{array}$ & Build by owner \\
\hline Style & $\begin{array}{l}\text { Planned at a } \\
\text { neighborhood or town } \\
\text { scale }\end{array}$ & & Incremental, informal \\
\hline Style & $\begin{array}{l}\text { Fitting in well-designed } \\
\text { regional plan }\end{array}$ & & $\begin{array}{l}\text { Not fitting any regional } \\
\text { plan, poor regional plan }\end{array}$ \\
\hline Style & $\begin{array}{l}\text { Highly designed } \\
\text { neighborhoods }\end{array}$ & $\begin{array}{l}\text { Design for major } \\
\text { buildings/spaces }\end{array}$ & $\begin{array}{r}\text { Little overall design or } \\
\text { planning input }\end{array}$ \\
\hline Style & Popular aesthetics & & Elite aesthetics \\
\hline Style & $\begin{array}{l}\text { Interspersed with or } \\
\text { adjacent to "natural" } \\
\text { areas }\end{array}$ & & Heavily urbanized \\
\hline
\end{tabular}

Finally, it should be noted that a number of authors either reject the term suburb as obsolete or propose that it is impossible to define suburbs due to their diversity (Archer 2005, 440). The former group have proposed alternative types of "postsuburban" environments such as technoburbs and urban realms (see Teaford 2008, x; Webber 1964). They have a point, particularly if they continue to define suburbs as primarily residential and middle class. For the purposes of this review, however, I include these postsuburban environments as types of suburbs and deal with them under various dimensions. As I note, alternatives to the residential suburb have been part of the scholarly debate on suburbs for almost a century.

\section{Dimensions}

A less complicated way to analyze this situation is to look at it one dimension at a time.

\section{Location}

Suburb is not a new word but rather comes from the Latin suburbium or "under the city", plural suburbia). The Oxford English Dictionary's (OED) first definition of suburbs thus refers to 
suburbs as a location: "The country lying immediately outside a town or city; more particularly, those residential parts belonging to a town or city that lie immediately outside and adjacent to its walls or boundaries" (Oxford English Dictionary 2011a; McManus and Ethington 2007, 319320). The dictionary provides examples of usage in English from the late fourteenth century. Suburb could mean both a literal place as well as the figurative outskirts of something such as a place, idea, or event (examples include the "suburbs" of Lent, of a narration, of sense...).

At their most basic, then, suburbs are outside of a town or city but belonging to it (Frost 1991). But what does this mean? It in part depends on where the boundary or wall between inside and outside a town or city is located, between what is urban and what is rural. Three examples demonstrate this difficulty.

- A city or town may be equivalent to an urbanized or metropolitan area. For example when talking about major cities in the world one might talk about "Los Angeles" but really mean the metropolitan area including such other municipalities as Beverly Hills, Santa Monica, and so on. A place at the edge or outskirts of a metropolitan area is clearly suburban-but how far inward do the "outskirts" extend?

- A city or town may be a form of municipality as in the City of Los Angeles representing that area that is officially designated as such. This designation has little relation to how "suburban" a place is in form and function - somewhere inside a "city" may be quite suburban in design or activities.

- The city may also refer to the downtown or the core of the historical or central city. A suburb would include other parts of the metropolitan area. This is a popular distinction in the U.S. but includes many older areas that may no longer be considered suburban by many.

This first definition - of a city or town as the whole metropolitan area--resonates with the definition of urban in urban studies, and in the OED, which defines urban as being everything that is not rural or wild. The U.S. census has been changing its definition of urban over the years but has a similar characterization. For 2010 the definition of an urban area is "a densely settled core of census tracts and/or census blocks that meet minimum population density requirements, along with adjacent territory containing non-residential urban land uses as well as territory with low population density included to link outlying densely settled territory with the densely settled core" (U.S. Census Bureau 2010). The census sets criteria for density as well; specifically urban census tracts have less than three square miles in area and population density at least 1,000 per square mile; with a minimum population of 2,500 people. Rural areas are all nonurban locations.

While the U.S. census does not define suburbs, many analysts have made a rough approximation by taking the urban (metropolitan) area and subtracting census-defined central city municipalities. This approach works better in areas with many local governments than in places like Texas where annexations mean that many central cities take up much of the metropolitan area. According to calculations published by Statistics Canada, if a similar 
definition were used in Canada, only 8\% of Calgary's population and 9\% of Winnipeg's but 73\% of Vancouver's would be suburban (Turcotte 2008).

A major difficulty with a locational definition is that urban areas come in a lot of different shapes and sizes with implications for the character of their suburbs. One estimate is that there are 50,000 urban areas in the world--but some are quite small and a suburb in a town of 5,000 is different in character to one in a city of 5 million (Satterthwaite 2007a, 2007b). Suburbs have been developed for a very long time now; is a place that was on the urban edge 50 or 100 years ago still a suburb even if it has a classic suburban form or is in a non-central municipality? What is the boundary of a town or city--the edge of its built up area, a political boundary, its boundary before motorized transportation or the automobile or world war two?

In part to get around this problem Fishman $(1987,117)$ distinguishes between a suburb, defined by location, and a "true suburb ... [that] must embody in its design a 'marriage of town and country,' a distinct zone set apart from by the solid rows of city streets and from rural fields." That is for "true" suburbs, he rejects a purely locational definition in favor of one based on physical characteristics and styles of building, design, and planning. Lineberry (1975) distinguishes between locational definitions from the U.S. census and cultural definitions like those of Johnson (2006) above - related to family type, segregation of home and work, and so on. He points out that, at least up to the 1970s, the two definitions were often "confused" (Lineberry 1975, 3).

For those who want to keep a locational definition but make it more nuanced and useful for comparative study, one approach is to imagine the city as rings around a core with variously inner (or first), middle (or second), and outer (third) ring suburbs (Johnson 2006; Green Leigh and Lee 2005). Gans $(1968,49)$ provides such a definition, comparing the inner city, the outer city of "stable residential areas that house the working-and middle-class tenant and owner", and the suburbs that are "the latest and most modern ring of the outer city, distinguished from it only by yet lower densities and by the often irrelevant fact of the ring's location outside the city limits." It is often unclear how much these outer suburbs overlap with those areas termed the suburban fringe, the peri-urban fringe, or the exurbs (Adell 1999). In Canada, the statistical agency has tried to operationalize this kind of definition as rings of a certain distance from the census tract containing the city hall of the most central municipality, with rings out a certain mummer of kilometers--0-5, 5-9, etc. (Turcotte 2008, 5). However this raises issues of what distances to use.

\section{Built Environment Characteristics}

Some people know suburbs when they see them because they have certain features that can be identified with the naked eye-detached housing, single-story factories and warehouses, campus-style low-rise office complexes, strip shopping centers, and large-scale shopping malls. Some of these characteristics can seem obviously related-such as density and detached housing. For example, Dunham-Jones and Williamson $(2009, \mathrm{x})$ describe suburbs as dominated by lower-density, single use private buildings designed as objects in a landscape, and funded or built by short-term investors such as real estate investment trusts and larger scale home 
builders; transportation is auto-oriented, with a looped and cul-de-sac network. Others talk about a landscape that is between the city and the country in form as well as location (Harris 2010; Fishman 1987).

Density is one favored characteristic for at least partially defining suburbs physically because it seems to be meaningful and easy to measure. Authors, however, differ as to whether to measure population, employment, or housing unit density; and if density gradients are most important (e.g. Gans 2009; Sridhar 2004; Harris 2010). Some early suburbs were more dense then the center cities, even in the U.S.; worldwide there are a number such examples today (Borchert 1996; Harris 2010). There are also related concepts such as building intensity (e.g. building bulk), building type, and perceived density that might be relevant in definitions (Forsyth et al. 2007).

Statistics Canada has attempted to construct a definition related to density and housing type. As they state: "we will refer to a neighbourhood as low density when at least two thirds of the occupied housing stock comprises single and semi-detached houses and mobile homes, that is, dwellings that take up the most space or area per occupant" (Turcotte 2008,6). They chose this over population density because of the problem of large census tracts with lots of nonresidential uses that still might be high density in the residential portions but low density overall. Density-based definitions have strengths in focusing on issues that are relevant to policy makers (i.e. they are things they can regulate), and that are relatively easy to measure (if researchers can agree on what kind of density to assess).

\section{Transportation}

Closely related to definitions based on physical features are functional definitions. Prominent among these are definitions related to means of gaining access to suburbs. One common definition is that suburbs are areas within commuting distance of the core city. Clapson, in a review of definitions, cites a common version, defining suburbs as "beyond the heart of the town ... [but] within its urban orbit" (that is within commuting distance), with a "geography...intermediate between the town centre and the countryside," and also depending on the town center for "shopping, leisure and other requirements" (Clapson 2003, 2; Thorns 1972; Douglass 1925; see review in Schnore 1957). Earlier, Douglass $(1925,8)$ had defined as suburban, lower density locations from which "the heart of the city can be reached conveniently, quickly, and at low cost." This is a viable definition in smaller areas, though as many contemporary urban areas have multiple cores, and employment is increasingly scattered across the metropolitan area, its underlying assumptions are less tenable in larger polycentric cities.

Others are less worried about what suburbs have in common in terms of transportation but how they are shaped by a dominant mode. For many authors, suburbs are primarily automobile-based. Flint $(2006,2)$ uses such a definition of suburbs: "spread-out, drive-thru, cardependent, newer-the-better suburbia." However, in many parts of the world, and periods of suburban history, some form of collective transportation-from railways and buses to vans and shared taxis-provides access to and around suburbs (Warner 1978). Suburbs could then be 
defined as the sum of different types e.g. street car suburbs plus automobile-based suburbs. This issue obviously overlaps in important ways with location but also with critical assessments as many authors (critically) equate suburbia with automobile-based sprawl.

\section{Activities}

A common approach when considering activities has been to see suburbs as primarily residential, providing bedroom areas for the larger metropolis. Others add that it must also be "well off, and marked by single-family homes" (Garreau 1991, 149). This view of suburbs as mostly residential was never the whole picture as even residential areas needed shops, schools, the offices of local professionals and tradespeople, faith communities, and such. Many industries suburbanized early as rail links, electrification, and trucking allowed; and people maintained some rural activities in early suburban areas (from raising chickens to market gardening) (Fogelsong 2005). But for many this definition of the primarily residential suburb was compelling, particularly though the 1960s.

Of course these days suburbs are more varied and a number of non-residential suburban types have become prominent making it hard to defend primarily residential definitions of the suburb. Some have tried to argue for new terms for nonresidential or mixed-use suburban areas. In 1925, Douglass distinguished between suburbs of "production" and "consumption" (Douglass 1925, 74-92; Harris 1943; Schnore 1957; Berger 1960). In the 1950s, Schnore drew on work by several others to propose that "residential suburbs" be distinguished from "employing satellites" (Schnore 1957, 122; Berger 1960). Many of the categories of environments used by more recent writers who focus on "postsuburbia" are mixed use areas or jobs centers (although some are declining suburbs) (Kling et al 2001; Lucy and Philips 2000, 4-6; Wu and Phelps 2008). For example edge cities mix office, retail, and hotels near residential in new developments (Garreau 1991). Fishman $(1987,184)$ coined the term "technoburb...[for a] peripheral zone, perhaps as large as a county, that has emerged as a viable socio-economic unit....Its residents look to their immediate surroundings rather than the [core] city for their jobs and other needs; and its industries find not only the employees they need but also the specialized services." However others have continued to use the term suburb-for example Hartshorn and Mueller (1992) call edge city type environments "suburban downtowns".

Some authors focus on the mix of activities in suburbs. For example, Duany et al.'s $(2000,3)$ Suburban Nation contrasts "suburban sprawl" with "traditional neighborhoods" both in suburban locations and presumably making up a large percentage of suburban areas in the U.S. While also a critical definition, it is based on activities. The traditional neighborhood involves "mixed-use, pedestrian-friendly communities of varied population, either standing free as villages or grouped into towns and cities" (Duany et al. 2000,4). Suburban sprawl in contrast is made up of five "homogenous components", subdivisions, shopping centers, office parks, civic institutions, and roadways - "which can be arranged in almost any way" (Duany et al. 2000, 5). As they claim: "They are polar opposites in appearance, function, and character: they look different, act differently, and they affect us in different ways." Overall such activity-based definitions have been evolving quite fast. 


\section{Political Places}

Suburbs may also be defined as municipalities or neighborhoods with some political or administrative role. The OED has examples of such usage from the mid-15 th century with suburbs being " 2 . Any of such residential parts, having a definite designation, boundary, or organization" (Oxford English Dictionary 2011b). In the U.S. a suburban municipality is outside the core city. While this definition is dealt with in the locational section-part of the reason this definition has been so much used is it deals not only with location but with political culture and activities as well. Some authors see this political independence as being core to the concept of suburbs (Beauregard 2006). As Teaford describes:

For Americans the notion of city limits has been vital to the concept of suburbia. Unlike Britain where the term suburb refers to a peripheral area whether inside or beyond a major city's boundaries, in the United States the federal census bureau and most commentators have defined suburbia as that zone within metropolitan areas but beyond central city limits. Because of the strong tradition of local self-rule in the United States, this political distinction between suburb and central city has been vital to discussions of suburban development, lifestyle, and policy. American suburbs are not simply peripheral areas with larger lawns and more trees than districts nearer the historic hub. They are governmentally independent political units that can employ the powers of the state to distinguish themselves from the city. (Teaford 2008, ix-x, italics in original)

\section{Sociocultural}

The sociocultural dimension is a prominent one in many definitions. As Healy $(1994$, xiii) states in the introduction to a collection of essays on Australian suburbs, "the terms 'suburb' and 'suburbia' have functioned as imagined spaces on to which a vast array of fears, desires, insecurities, obsessions and yearnings have been projected and displaced."

Some of these definitions overlap a great deal with styles of building (below). For example Fava's $(1956,34)$ "Suburbanism as a way of life" pointed out that suburbs share three sets of traits: "more than their disproportionate share of young married couples and their children"; "made up largely of families of middle-class status," and with certain physical qualities such as "private" (detached) houses, low densities, and open space. 'As Nicolaides and Weise $(2006,7)$ describe in their introduction to the Suburb Reader, others allude to how these features are elaborated as ways of life, defining suburbs as "places shaped by elevated values for home ownership, secluded nuclear families, privacy, a distinctive, gendered division of labor, social exclusivity, semirural landscapes, dislike of cities, political home-rule, etc." Some scholars emphasize the economic and regulatory tools for creating and maintaining this conformity but these are rarely posed as definitions (Fogelsong 2005).

A subset of such socio-cultural definitions examine the intersection between social and physical dimensions, focusing on "Western" style suburbs in low and middle income countries. For example King (2004) describes as suburban middle and upper middle class villas in Asia, particularly those with European or North American themes (also Fishman 2003). As Harris 
(2010) points out lower income squatter settlements, even ones in suburban locations in such countries, are rarely described as suburbs. In contrast, in places such as Europe and Australasia, suburban poverty and "locational disadvantage" in suburban public housing and other low income areas is a key concern (Maher 1994). Obviously this is an area demanding more clarity.

Suburbs are also not all socially homogenous even within one metropolitan area. For some decades scholars have been emphasizing how suburbs, as well as attracting middle class and elite groups, have also attracted migrants from rural areas who wanted cheap land where they could build their own houses incrementally, and grow some of their own food or work in suburban manufacturing (Berger 1960; Nicolaides and Weise 2006). Others have pointed to growing communities of international migrants, lower income groups, gay households, and other diverse populations moving to suburbs. Still others propose a mixture related to settlement age e.g. people residing in villages and towns swallowed up into a metropolitan area. As Teaford remarks (2008), with perhaps a little boosterism:

American suburbs include some of the nation's most densely populated communities as well as areas zoned to accommodate more horses than human beings. Suburbia reflects the ethnic diversity of America more accurately than the central cities, providing homes for Hispanics, Asians, and blacks as well as non-Hispanic whites. It comprises slums as well as mansions, main streets as well as malls, skyscrapers as well as schools. Some suburbs are particularly gay-friendly; others are planned for senior citizens. Some are known for their fine schools; others are examples of educational failure. (Teaford 2008, xiii-xiv),

As Nicolaides and Weise (2006) explain, this diversity within and between suburbs has challenged earlier definitions, particularly in the field of history in the United States:

The most intensive argument has pivoted around questions of class and race: Was a suburb only a suburb when it was white and middle or upper class? Pioneering scholars in the field...implied that the answer was yes.... By the 1990s, however, suburban 'revisionists' had begun to challenge this 'orthodox' version of suburbia for what it omitted: in particular, industry, multifamily housing, blue-collar workers, ethnic and racial minorities, and the poor. (Nicolaides and Weise 2006, 7-8)

Globally, suburban public housing estates, industrial worker suburbs, and self-build suburbs (including squatter settlements, shanty towns, mobile home parks, and low-cost subdivisions) also make it hard to defend a view of suburbs as essentially white and affluent (Harris 2010; Forsyth 2012). The alternative in some fields has been a definition based on suburbanization, or the process of decentralization of jobs and housing whether voluntary or involuntary (Nicolaides and Weise 2006, 8). However, as more people are "suburban-born and bred," and many move directly to suburbs bypassing the core city, such a definition based on decentralization may need to be enlarged (Fava 1975, 10; Harris 2010). 


\section{Styles of Building, Design, and Planning}

Key to how new home purchasers interact with suburban developments, and urban planners and designers think about them, is how they are designed and built. Many authors have pointed out how suburbs meld town and countryside in a unique blend (Fishman 1987; Archer 2011). This is a central tenet of the garden tradition of suburban design (Howard 1902).

How this blend is achieved depends on how suburbs get constructed. Many suburban homes are built one by one to the specifications of the owner, or indeed by the owner over time. Others are built by developers and builders in subdivisions of various scales, and with different levels of fit in various neighborhood, municipal, or regional plans. Many now use prefabrication and other standard building techniques to keep costs down.

Criticisms of "suburbia" frequently focus on one or two such styles e.g. tract housing, that is they define suburbia as exemplified by these problematic forms. At larger scale the great debate is over sprawl-thus overlapping with the critical assessment type of definition-whether it is unplanned and incremental or planned in a way that contributes positively to the region (Hayden 2004, 1-2).i

\section{Time}

Along with density and location, Harris proposes "newness" as a key criterion for defining suburbs (Harris 2010, 29). As he points out, however, some authors such as Clarke (1966) propose that this period of relative newness lasts only a few years and others such as Whitzman (2009) give examples lasting many decades. One issue with such definitions is how to deal with older towns and villages that over time are surrounded by new suburban development, and functionally become suburbs.

Other definitions of suburbs focus on development after a certain time period, for example post-World War Two developments. This is often in combination with some other dimension such as location or building type (Forsyth 2005). Such definitions are most useful in places like the U.S. where this has been a key period of suburbanization. An alternative is to define types of suburbs as the total of different periods of suburbs. Such historical classifications are rarely used to explicitly define suburbs, but suburbs are presumably made up of the sum total of the different types of suburbs (e.g. Lang et al 2005; Hayden 2003).iii

\section{Critical Assessments}

Many definitions of suburbs are really catalogs of their ills. According to the OED, this kind of definition has been around at least since the 17th century when suburban areas were seen as more lawless than the core city (Oxford English Dictionary 2011b def. 4). By the nineteenth century the term "suburban" was used for those "having the inferior manners, the narrowness of view, etc., attributed to residents in suburbs" (Oxford English Dictionary 2011b). As Barker $(2009,13)$ describes in his defense of British suburban life, for many in the press and design professions to "call anything or anyone 'suburban' is to utter a put-down, an anathema, a curse." 
In such cases the commentator is frequently focusing on certain kinds of suburbs that have specific problems--social, aesthetic, environmental, or cultural. Other areas that under a locational definition would be classed as suburbs are defined as something else--small towns, employment areas, new towns, and so on. A cluster of urban design critiques point to the lack of urbanity in suburbs, with suburbs defined as lacking positive urban features (e.g. Montgomery 1998). iv

There is a long and rich history of such critiques, with a number of authors providing substantial reviews of them (Eichler and Kaplan 1967; Popenoe 1977; Gans 1963; Forsyth 2005; Bruegmann 2006). Of these more critical assessments, the ones that are most easy to defend are environmental critiques of suburbia as energy inefficient, land grabbing, and water quality eroding. But even these are hard to sustain across all suburbs. For example, any suburban areas are transit oriented or else blend natural systems with development (Crewe and Forsyth 2011). Overall these are important "negative" definitions that specify through critique.

\section{Indices}

Finally are indices or complex methods for defining and distinguishing suburbs - here again suburbs are the sum total of different types. In a famous example, Orfield (2002) used cluster analysis applied to almost 5,000 suburban places in the U.S., distinguishing them according to fiscal capacity (and of course location outside the core city). He proposed six suburban clusters or types including three "at risk" types (segregated, older, low-density), two types of suburban jobs centers (best off fiscally), and bedroom suburbs. Similarly, Mikelbank (2004) used cluster analysis to create a typology of U.S. census-defined suburbs based on demographic characteristics, economic variables, physical features, and some aspects of government. Data were drawn from the population, economic, and government censuses. From this he created 10 types of suburbs, ranging from traditional wealthy bedroom suburbs though working class diverse suburbs (p. 950). Hanlon et al. $(2009,261)$ similarly developed an "index of suburban transformation" related to population, income, and poverty (see also Vicino 2008).

Sprawl indices that can distinguish suburbs from historic areas by features such as density and street pattern are another of this style (e.g. Ewing et al. 2002). These are useful and data rich ways to define types of suburbs and could be further developed to define suburbs as a whole.

\section{Conclusions}

Given all the confusion around the term one option is to give up on the term suburb. There are two ways to do this. The first is to replace it with more specific environmental types such as postwar subdivision, edge city, and office park. A metropolitan area would be composed not of core city and suburbs but of a variety of such environments (Hayden 2004). This has some potential among suburban experts who are typically aware that suburbs are quite diverse. In comparative work it may be easier to examine specific suburban types. Such an approach may, however, be a challenge for those working on more general processes of urban growth or speaking to the public. Terms such as neighborhood and community are similarly murky but also hard to give up completely. 
A variation on the strategy is to focus on specific features such as location, density, street pattern, or historical period of development and not use the term suburb. This is in fact quite often done in urban studies. Many research projects on, say, environments and health do not state that specific environments are suburban but rather that their street patterns are dominated by large blocks (and some such areas will of course be located in core cities, but more are likely to be in suburbs). This approach allows research variables to be clearly conceptualized. For example Knapp and Zhao's (2009) overview of “Smart Growth and Urbanization in China" does not mention the term suburbs though it is clearly dealing with development in suburban locations and it has a number of very compelling illustrations of outer urban development, freeways, and a low-density subdivision (also Song and Ding 2009). Rather their paper deals with smart growth dimensions such as land use mix and farmland preservation. I have certainly used this strategy in my own publications. However, non-experts can find it hard to interpret such variables so researchers often have to provide examples using terms such as "suburban apartment area" or "low-density suburb."

Alternatively it may be possible to keep the term. One way to do this is to better distinguish between types of suburbs - so that all references to suburbs are qualified by an adjective. This makes sense because different types of suburbs will have different problems and different planning needs. Many authors today deal with this situation by focusing on fairly clearly defined types of suburbs such as Fishman's $(2003,1)$ "American-style 'suburbs of prosperity'" or the "ethnoburb" (Li 1998). If such suburbs are defined with some precision, then they could be the bases of conceptual models, larger theories, and thoughtful practice.

To define suburbs as a whole, rather than types of suburbs, is more complex. As mentioned earlier, following an extensive international review of suburban scholarship, Harris (2010) proposed a definition based on location, density, and newness. Of these, location can be the most consistently applied. Suburbs, at their simplest, are more recently developed parts of an urban or metropolitan area, outside the core or historical city area. Even this definition raises questions. How far from the center of a metropolis do the suburbs start? How far do they extend? Depending on the age of the metropolitan area, size of the core, and forms of transportation, this could be a very large area, developed over a long time and representing a wide variety of environments. In this case it may well be necessary to then define sub-types of suburbs, such as the suburban rings used by some authors. Density and newness are a little more complex. As Harris (2010) points out, while not common, some urban areas have suburbs that are denser than their core cities. While newness seems more obvious as part of a definition, it too raises questions. How old does a suburb need to be before it is part of the core or historic city? How should one deal with older fragments of development surrounded by new suburbs and linked physically and functionally to them? A suburban index could, perhaps, help deal with some of these problems.

As urbanization continues, making metropolitan areas more complex, those studying and working on urban issues will need to understand their various components. The term suburb represents a long-standing and viable term for describing development beyond the core city. 
Alternatives such as "peri-urban" are no more clearly defined. Suburbs do have important features in common, however. Because of their location and relative newness such locations are likely to have a particular range of functions, transportation modes, social characters, and physical features. More clearly distinguishing suburbs from other kinds of development, and different types of suburban environments, can help both those who want to understand suburbs and those involved in planning and (re)developing them.

\section{Acknowledgements}

I would like to thank the editor, two anonymous reviewers, and Katherine Crewe for comments on this paper.

\section{Notes}

ii Some definitions of suburbs stress their homogeneity, middle class character, and exclusivity. Certain subtypes have garnered great interest: the gated enclave; golf-course communities; McMansion estates, ethnoburbs, or ecoburbs (Grant and Mittlesteadt 2004; Li 1998; Crewe and Forsyth 2011).

ii In terms of the central question of this paper, work in this area tends to focus on specific types of suburbs rather than suburbs as a whole. For example, Forsyth and Crewe (2009a, 58-59) focus on highly planned suburban developments since the second world war, including those designed to emphasize neighborhood planning, architecture and aesthetics, social diversity, designed enclaves, low-density ecoburbs, more transit efficient eco cities, and "technovilles." iii For example Hayden $(2003,4-5)$, in her history of suburbia in the U.S., describes how "the history of suburban construction can be understood as the evolution of seven vernacular patterns. Building in borderlands began about 1820. Picturesque enclaves started around 1850 and streetcar buildouts around 1870. Mail-order and self-built suburbs arrived in 1900. Massproduced, urban-scale "sitcom" suburbs appeared around 1940. Edge nodes coalesced around 1960. Rural fringes intensified around 1980. All these patterns survive in the metropolitan areas of 2003. Many continue to be constructed."

iv Aesthetic critiques of suburbia are a particularly striking example. Attacks typically focus on areas that sport obviously prefabricated houses or many similar looking buildings. Such areas house lower and middle income people--though conspicuous consumption by those who have not been educated in design is also a focus for aesthetic critiques (as in the case of critiques of McMansions). Left out from these criticisms are architect-designed homes in suburban areas-even though they may well use more energy, deplete more habitat, and exclude more low income people from what are often pleasant and well-serviced areas. This is a point that has been made before (e.g. Bruegmann 2006; Forsyth and Crewe 2009b). 


\section{References}

Adell, G. 1999. Theories and models of the peri-urban interface: a changing conceptual landscape. London: Development Planning Unit, http://discovery.ucl.ac.uk/43/1/DPU PUI Adell THEORIES MODELS.pdf

Archer, J. 2005. Architecture and Suburbia. Minneapolis: University of Minnesota Press.

Archer, J. 2011. Suburbs. In T. Banerjee and A. Loukaitou-Sideris eds. Companion to Urban Design. London: Routledge

Barker, P. 2009. The Freedoms of Suburbia. London: Francis Lincoln.

Bassett, E.M. 2009. Framing the Oregon land use debate: an exploration of Oregon voters' pamphlets 1970-2007. Journal of Planning Education and Research 29, 2: 157-172.

Beauregard, R. 2006. When America became Suburban. Minneapolis: University of Minnesota Press.

Berger, B. 1960. Working-Class Suburb: A Study of Auto Workers in Suburbia. Berkeley: University of California Press.

Borchert, J. 1996. Residential city suburbs: the emergence of a new suburban type 1880-1930. Journal of Urban History 22: 283-307.

Bruegmann, R. 2006. Sprawl: A Compact History. Chicago: University of Chicago Press.

Caplan, N. and S. Nelson. 1973. On being useful: the nature and consequences of psychological research on social problems. American Psychologist 28, 3: 199-211.

Clapson, M. 2003. Suburban Century. Oxford: Berg.

Clapson, M, and R. Hutchinson. 2010. Introduction: suburbanization in global society. In M Clapson and R. Hutchinson eds. Suburbanization in Global Society. Bingley, UK: Emerald.

Clarke, S.D. 1966. The Suburban Society. Toronto: University of Toronto Press.

Crewe, K, and A. Forsyth. 2011 Compactness and Connection in Environmental Design: Insights from Ecoburbs and Ecocities for Design with Nature. Environment and Planning B 38, 2: 267-288.

Douglass, H.P. 1925. The Suburban Trend. New York: The Century Company,

Duany, A. E. Plater-Zyberk, and J. Speck. 200. Suburban Nation: the Rise of Sprawl and the Decline of the American Dream. New York: North Point Press.

Dunham-Jones, E. and J. Williamson. 2009. Retrofitting Suburbia. New York: Wiley.

Eichler, E. and M. Kaplan. 1967. The Community Builders. Berkeley: University of California Press.

Ewing, R., R. Pendall, D. Chen. 2002. Measuring Sprawl and its Impact. Washington DC: Smart Growth America. http://www.smartgrowthamerica.org/sprawlindex/MeasuringSprawl.PDF

Fava, S. 1956. Suburbanism as a way of life. American Sociological Review 21, 1: 34-37.

Fava, S. 1975. Beyond suburbia. The Annals of the American Academy of Political and Social Science 422: 10-24.

Fishman, R. 1987. Bourgeois Utopias: The Rise and Fall of Suburbia. New York: Basic Books.

Fishman, R. 2003. Global Suburbs. University of Michigan working paper, URRC-0301: http://sitemaker.umich.edu/urrcworkingpapers/all urrc working papers\&mode=single \&recordID=308464\&nextMode=list 
Flint, A. 2006. This Land: The Battle over Sprawl and the Future of America. Baltimore: the Johns Hopkins University Press.

Fogelsong, R.M. 2005. Bourgeois Nightmares: Suburbia 1870-1930. New Haven: Yale University Press.

Forsyth, A. 1999. Constructing Suburbs. New York: Routledge.

Forsyth, A. 2005. Reforming Suburbia. Berkeley: University of California Press.

Forsyth, A. 2012. Global suburbia. Draft manuscript.

Forsyth, A. and K. Crewe. 2009a. A typology of comprehensive designed communities since the Second World War. Landscape Journal 28, 1: 56-78.

Forsyth, A. and K. Crewe. 2009b. New visions for suburbia: reassessing aesthetics and placemaking in modernism, imageability, and new urbanism. Journal of Urban Design 14, 4: 415-438.

Forsyth, A. J.M. Oakes, K. H. Schmitz, and M. Hearst. 2007. Does Residential Density Increase Walking and Other Physical Activity? Urban Studies 44, 4: 679-697.

Frost, L. 1991. The New Urban Frontier. Kensington: University of New South Wales University Press.

Gans, Herbert. 1963. Effects of the move from city to suburb. In The Urban Condition, Leonard Duhl ed. New York: Basic Books.

Gans, H. 1968. People and Plans New York: Basic Books.

Gans, H. 2009. Imagining the suburban future. Robert A. Catlin Memorial Lecture, Bloustein School of Planning and Public Policy. Rutgers, February 5.

Garreau, J. 1991. Edge City. New York: Doubleday.

Gober, P. and M. Behr. 1982. Central cities and suburbs as distinct place types: myth or fact? Economic Geography 58, 4: 371-385.

Goetz, E. 2008. Words matter: the issue of framing and the case of affordable housing. Journal of the American Planning Association 74, 2: 222-229.

Grant J. and L. Mittelsteadt. 2004. Types of gated communities. Environment and Planning B 31: 913.

Green Leigh, N. and S. Lee. 2005. Philadelphia's space in between: inner-tine suburb evolution. Opolis 1, 1: 13-32.

Hanlon, B. J.R. Short, and T. Vicinio. 2009. Cities and Suburbs. New York: Routledge.

Harris, R. \& Larkham, P.J. 1999. Suburban foundation, form and function. In n Harris, R. \& Larkham, P. eds. Changing Suburbs. Foundation, Form and Function. New York: E. \& F.N. Spon.

Harris, C.D. 1943. Suburbs. American Journal of Sociology 49, 1: 1-13.

Harris, R. 2010. Meaningful types in a world of suburbs. In M Clapson and R. Hutchinson eds. Suburbanization in Global Society. Bingley, UK: Emerald.

Hartshorn, T. and P. Muller. 1992. The suburban downtown and urban economic development today. In Sources of Metropolitan Growth, Mary McLean ed. New Brunswick: Rutgers University Press.

Harvard Law Review Association. 2004. Locating the suburb. Harvard Law Review 117: 20032022.

Hayden, D. 2003. Building Suburbia: Green Fields and Urban Growth, 1820-2000. New York: Pantheon Books. 
Hayden, D. 2004. A Field Guide to Sprawl. New York: Norton.

Healy, C. 1994. Introduction. In S. Ferber, C. Healey, and C. McAuliffe eds. Beasts of Suburbia: Representing Cultures in Australian Suburbs. Melbourne: Melbourne University Press.

Healey, P. 2009. The pragmatic tradition in planning thought. Journal of Planning Education and Research 28: 277-292.

Hillery, G. 1955. Definitions of community. Areas of agreement. Rural Sociology 20: 111-123.

Hodge, D. and J. Lacasse. 2011. Ranking disciplinary journals with the Google Scholar H-Index: A new tool for constructing cases for tenure, promotion, and other professional decisions. Journal of Social Work Education 47, 3: 579-596.

Howard, E. 1902, orig. 1898. Garden Cities of Tomorrow. London: Sonnenschein.

laquinta, D.I. and A. W. Drescher. 1999. Defining the peri-urban: rural-urban linkages and institutional connections. Rome: UN Food and Agriculture Organization, http://www.fao.org/DOCREP/003/X8050T/x8050t02.htm\#P13_2357

Johnson, L.C. 2006. Style Wars: revolution in the suburbs? Australian Geographer 37, 2: 259276.

King, A. D. 2004. Spaces of Global Cultures: Architecture Urbanism Identity. London: Routledge.

Kling, R., S. Olin, and M. Poster eds. 1991. Postsuburban California. Berkeley: University of California Press.

Knapp, G. and X. Zhao. 2009. Smart growth and urbanization in China. In Song, Y. and C. Ding, eds. 2009. Smart Urban Growth for China. Cambridge, MA: Lincoln Institute for Land Policy.

Kurtz, R. and J.B. Eichler. 1958. Fringe and suburb: A confusion of concepts. Social Forces 37, 1: 32-37.

Lang, R. J. Le Furgy, and A.C. Nelson. 2006. The six suburban eras of the United States. Opolis 2, 1: 65-72.

Li, W. 1998. Anatomy of a new ethnic settlement: The Chinese ethnoburb in Los Angeles. Urban Studies 35, 3: 479-501.

Lineberry, R. 1975. Suburbia and the metropolitan turf. Annals of the Academy of Political and Social Science 422: 1-9.

Lucy, W. and D.L. Phillips. 2000. Confronting Suburban Decline. Washington, DC: Island Press.

Maher, C. 1994. Residential mobility, locational disadvantage, and spatial inequality in Australian cities. Urban Policy and Research 13, 3: 185-191.

McManus, R. and P. J. Ethington. 2007. Suburbs in transition: new approaches to suburban history. Urban History 34, 2: 317-337.

Mikelbank, B. 2004. A typology of U.S. suburban places. Housing Policy Debate 15, 4: 935-964.

Montgomery, J. 1998. Making a city: Urbanity, vitality, and urban design. Journal of Urban Design 3, 1: 93-116.

Mumford, L. 1961. The City in History: Its Origins, Its Transformations, and Its Prospects. New York: Harcourt, Brace and World.

Nicolaides, B. and A. Wiese. 2006. Introduction. In B. Nicolaides. and A. Wiese eds. The Suburb Reader. New York: Routledge.

Orfield, M. 2002. American Metropolitics: The New Suburban Reality. Washington, DC: Brookings Institution Press. 
Oxford English Dictionary. 2011a. Suburb.

http://www.oed.com/viewdictionaryentry/Entry/193229

Oxford English Dictionary. 2011b. Suburban http://www.oed.com/view/Entry/193230)

Popenoe, David. 1977. The Suburban Environment. Chicago: University of Chicago Press.

Satterthwaite, D. 2007a. The scale of urban change worldwide 1950-2000 and its underpinnings. IIED Human Settlements Discussion Paper. http://www.iied.org/urban/Urban Change.html

Satterthwaite, D. 2007b. The transition to a predominantly urban world and its underpinnings. IIED Human Settlements Discussion Paper. http://www.iied.org/pubs/display.php?o=10550IIED

Schnore, L. 1957. Satellites and suburbs. Social Forces 36, 2: 121-127.

Schon, D. and M. Rein. 1994. Frame Reflection: Towards the Resolution, of Intractable Policy Controversies. New York: Basic Books

Song, Y. and C. Ding, eds. 2009. Smart Urban Growth for China. Cambridge, MA: Lincoln Institute for Land Policy.

Sridhar, K. 2004. Cities with suburbs: Evidence from India. National Institute of Public Finance and Policy Working Paper. http://www.nipfp.org.in/working paper/wp04 nipfp 023.pdf

Teaford, J. 2008. The American Suburb: The Basics. New York: Routledge.

Thorns, D. 1972. Suburbia. London: McGibbon and Kee.

Turcotte, M. 2008. The city/suburb contrast: How can we measure it? http://www.statcan.gc.ca/pub/11-008-x/2008001/article/10459-eng.htm\#2

U. S. Census Bureau. 2010. 2010 Census Urban and Rural Classification and Urban Area Criteria http://www.census.gov/geo/www/ua/2010urbanruralclass.html

U.N. Department of Economic and Social Affairs. 2010. World Urbanization Prospects: The 2009 Revisions, Highlights. New York: United Nations.

Vicino, T. 2008. The spatial transformation of first-tier suburbs, 1970 to 2000: The case of metropolitan Baltimore. Housing Policy Debate 19, 3: 479-517.

Warner, S. 1978, first ed. 1962. Crabgrass Frontier: The Process of Growth in Boston (18701900). Cambridge: Harvard University Press.

Webber, M. 1964, The urban place and the nonplace urban realm. In M. Webber ed. Explorations into Urban Structure. Philadelphia: University of Pennsylvania Press, Philadelphia.

Whitzman, C. 2009. Suburb, Slum, Urban Village: Transformations in Toronto's Parkdale Neighborhood, 1975-2002. Vancouver: UBC Press.

Williams, R. 1976. Keywords. New York: Oxford.

Wittgenstein, L. (2009 orig.) 1953. Philosophical Investigations. 4th ed. P.M.S. Hacker and J. Schulte eds. and trans. Oxford: Wiley-Blackwell.

Wu, F. and N. Phelps. 2008. From suburbia to post-suburbia in China? Aspects of the transformation of the Beijing and Shanghai global city regions. Built Environment 34: 464-481. 